\title{
SOD PRODUCTION AND NUTRIENT EXTRACTION BY EMERALD ZOYSIAGRASS WITH SPLIT NITROGEN APPLICATIONS
}

\section{Produção de tapetes e extraşão de nutrientes pela grama esmeralda com parcelamento de doses de nitrogênio}

Leandro José Grava de Godoy ${ }^{1}$; Roberto Lyra Villas Bôas²; Clarice Backes ${ }^{3 *}$; Edhielle Vanessa de Lima Soares ${ }^{4}$; Alessandro José Marques Santos ${ }^{5}$; Claudinei Paulo de Lima ${ }^{6}$; Dirceu Maximino Fernandes ${ }^{7}$

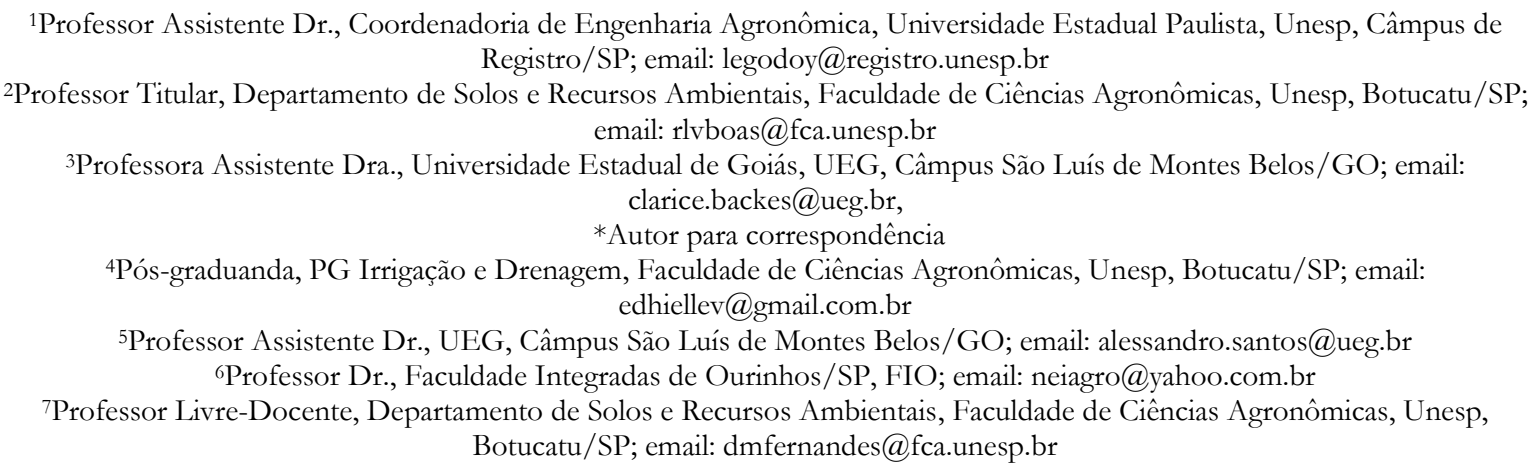

Artigo enviado em 27/04/2017, aceito em 01/09/2017 e publicado em 20/12/2017.

\begin{abstract}
Nitrogen is the nutrient that provides the best grass growth responses, and proper nitrogen fertilization can enable the formation of sod in less time and firm enough to be handled after harvest. The aim of this study was to evaluate production and nutrient extraction of Emerald zoysiagrass (Zoysia japonica Steud.) according to the splitting of nitrogen doses. Treatments consisted of five doses $\left(0,150,300,450\right.$ and $\left.600 \mathrm{~kg} \mathrm{ha}^{-1}\right)$ divided in three or six applications., The $\mathrm{N}$ dose of $400 \mathrm{~kg} \mathrm{ha}^{-1}$, divided in four applications, provided the formation of Emerald zoysiagrass sods six months after the previous sod harvest. Nutrient extraction by Emerald zoysiagrass occurs in the descending order, at kg ha-1: N (207) > K (57) > (Ca) > S (27) > P (14) $=\mathrm{Mg}(14)$.
\end{abstract}

Keywords - Turf, nitrogen fertilization, percent ground cover, Zoysia japonica Steud.

Resumo - O nitrogênio é o nutriente que proporciona as maiores respostas no crescimento das gramas e a adubação nitrogenada adequada pode proporcionar a formação do tapete em menor tempo e firme para ser manuseado após a colheita. Objetivou-se com o trabalho avaliar a produção e a extração de nutrientes pelos tapetes da grama Esmeralda em função do parcelamento de doses de nitrogênio. O experimento foi realizado em fazenda de produção de grama, em Itapetininga, SP. Os tratamentos foram constituídos por cinco doses de N: 0, 150, 300, 450 e $600 \mathrm{~kg} \mathrm{ha-1}$, divididos em três ou seis aplicações. A dose de $400 \mathrm{~kg} \mathrm{ha}^{-1} \mathrm{~N}$, parcelada em quatro aplicações, proporcionou a formação de tapetes de grama Esmeralda, seis meses após a colheita do tapete anterior. A extração de nutrientes pela grama esmeralda obedece a seguinte ordem decrescente, em kg ha-1 $: \mathrm{N}(207)>\mathrm{K}(57)>\mathrm{Ca}(45)>\mathrm{S}(27)>\mathrm{P}(14)=\mathrm{Mg}(14)$.

Palavras-chave - Gramado, adubação nitrogenada, taxa de cobertura do solo, Zoysia japonica Steud.

\section{INTRODUCTION}

Emerald zoysiagrass (Zoysia japonica Steud.) can form high-quality turf because of its great tolerance to high temperatures, drought, pests, and trampling, especially when compared with cold-season grasses (PATTON; REICHER, 2007). According to Zanon and Pires (2010), in the state of São Paulo, Brazil, Emerald zoysiagrass has become a synonym for turfgrass, as once was Bahia grass in the mid-
90 s, occupying an estimated growing area of 12,000 ha, with 5,000 in São Paulo state, concentrated mainly in the region of Itapetininga.

The growing demand of the consumer market regarding the final quality of turfs are two of the main factors driving producing areas, especially those near great consumer centers. Among other expansion factors are the development of new varieties, release of specific products and machinery for turfs, adaptation and improvement of 
production techniques, implementation and maintenance of turfs, and mainly fertilization (GODOY; VILLAS BÔAS, 2005).

Though there are no official recommendations with respect to fertilization for grass production, studies conducted in the state of São Paulo have indicated that $\mathrm{N}$ doses of 310 to $408 \mathrm{~kg} \mathrm{ha}^{-1}$ would allow for the production of Emerald zoysiagrass sods with sufficient resistance to be handled after harvest (GODOY et al., 2007; BACKES et al., 2009). Nitrogen doses between 354 and $365 \mathrm{~kg} \mathrm{ha}^{-1}$ increased the resistance of bermudagrass (Cynodon dactylon (Pers.) L) sods and thus their liftability after harvest, which may thus provide a greater yield for the area (LIMA et al., 2010). A N dose of $430 \mathrm{~kg} \mathrm{ha} \mathrm{ha}^{-1}$ allowed the production of St. Augustine grass sods resistant to harvest and transport, in the period of ten months (GODOY; VILLAS BOAS; BACKES, 2012).

Higher $\mathrm{N}$ doses may reduce the production time of grass sods; however, excessive doses force the growth of shoots over toots, thereby reducing the sod's liftability after the harvest (BACKES et al., 2009). Nevertheless, in the reported experiments, the authors did not investigate the splitting of nitrogen fertilization, which was divided into six (GODOY et al., 2007), three (LIMA et al., 2010), or a single application (BACKES et al., 2009). In the last case, it fertilization was performed with uncomposted sewage sludge as the $\mathrm{N}$ source.

Splitting high $\mathrm{N}$ doses (300 to $400 \mathrm{~kg} \mathrm{ha}^{-1}$ ) into few applications may damage the turf shoots or, mainly, reduce the use efficiency of the nitrogen fertilizer. Backes et al. (2010) concluded that only 26 and $15.5 \%$ of the applied $\mathrm{N}$ was accumulated by Emerald zoysiagrass when uncomposted sewage sludge was applied in a single occasion, at the doses of 100 and $400 \mathrm{~kg} \mathrm{ha}{ }^{-1} \mathrm{~N}$, respectively. In the USA, the commonly recommended $\mathrm{N}$ doses for Z. japonica production do not exceed $60 \mathrm{~kg} \mathrm{ha}^{-1}$ per application (CHRISTIANS, 2011; TURNER, 2003).

Knowing the nutrient extraction properties of a grass may make it possible to understand factors related to the mineral nutrition of its crop, and consequently to calibrate fertilizer doses for each species, thereby preventing losses during fertilization.

The aim of this study was to evaluate the production and extraction of nutrients by Emerald zoysiagrass sod according to the splitting of nitrogen applications. The methods of percent ground cover of the turfgrass determination were also evaluated through digital image analysis.

\section{MATERIAL AND METHODS}

The experiment was conducted on Itograss

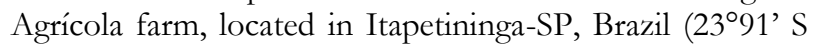
and $48^{\circ} 03^{\prime} \mathrm{W}, 636 \mathrm{~m}$ ). The area had been used for the previous four years for commercial production of grass mechanically harvested as sods.

The soil in the experimental area is a dystrophic red Latosol (Haplortox) with a highly clayey texture, according to the nomenclature given by the Brazilian Soil Classification System of Embrapa (SANTOS et al., 2013).
The soil properties before the implementation of the experiment were $\mathrm{pH}\left(\mathrm{CaCl}_{2}\right) 4.4 ; 28 \mathrm{~g} \mathrm{dm}^{-3}$ organic matter; $10 \mathrm{mg} \mathrm{dm}{ }^{-3} \mathrm{P}$ (resin); 53, 0.2, 16, and $5 \mathrm{mmol}_{\mathrm{c}} \mathrm{dm}^{-3}$ $\mathrm{H}^{+}+\mathrm{Al}^{+3}, \mathrm{~K}, \mathrm{Ca}$, and $\mathrm{Mg}$, respectively; and $28 \%$ base saturation. The soil particle analysis revealed 373,735 , and $46 \mathrm{~g} \mathrm{~kg}^{-1}$ sand, clay, and silt, respectively.

In the experiment, we used Emerald zoysiagrass (Zoysia japonica Steud), a rhizomatous, stoloniferous species whose sods produced can be harvested from the entire area, since the sub-superficial rhizomes will ensure regrowth and formation of new sod.

Liming was performed 30 days after the harvest of the previous sod (HPS), by manually applying $3.6 \mathrm{Mg} \mathrm{ha}^{-1}$ dolomitic line (91\% PRNT) on the soil surface, aiming to increase base saturation to $70 \%$. Basic fertilization was also applied, using $500 \mathrm{~kg} \mathrm{ha}^{-1}$ of the 04-14-08 formula, on topsoil, At $75 \mathrm{HPS}, 70 \mathrm{~kg} \mathrm{ha}^{-1} \mathrm{~K}_{2} \mathrm{O}$ were added in the form of $\mathrm{KCl}$, totaling $110 \mathrm{~kg} \mathrm{ha}^{-1} \mathrm{~K}_{2} \mathrm{O}$.

The experimental plots measured $2.5 \times 5 \mathrm{~m}$ plus a $0.5 \mathrm{~m}$ border on the four sides of the plot, leaving a usable area of $1.5 \times 4 \mathrm{~m}$. A randomized-block experimental design was adopted, with four replications and treatments set in a factorial arrangement with five $\mathrm{N}$ doses $(0,150,300,450$, and $600 \mathrm{~kg} \mathrm{ha}^{-1}$ ) split into three or six applications. The $\mathrm{N}$ source utilized was urea $(44 \% \mathrm{~N})$, applied manually on topsoil, which was irrigated with a water depth of $6 \mathrm{~mm}$ until $24 \mathrm{~h}$ after application. Nitrogen fertilization in the three plots was performed at 60 (Jan), 124 (Mar), and 227 (May) HPS, and the application in six plots occurred at 60 (Jan), 90 (Feb), 124 (Mar), 197 (Apr), 227 (May), and 296 (Jun) HPS.

The turf was spray-irrigated by a central pivot. Frequency and depths were determined based on the rainfall, applying a depth of approximately $6 \mathrm{~mm}$ whenever necessary (two days without rainfall). Weed control in the experimental area was carried out manually. Precipitation (in $\mathrm{mm}$ ) and maximum, mean, and minimum air temperature (degrees Celsius), and potential evapotranspiration (in $\mathrm{mm}$ ) data from the municipality of Itapetininga (Figures 1 and 2) were provided by the Integrated Agro-Meteorological Information Center belonging to the Agronomic Institute of Campinas (CIIAGRO, 2016).

Four cuts (124, 192, 227 and 296 HPS) were performed to maintain the turfgrass at the appropriate height $(3 \mathrm{~cm})$ using a mini tractor with mower. The clippings were not collected and deposited on the turf.

Sods were harvested mechanically by a harvester coupled to the tractor. One day before the harvest, the area was irrigated and a road roller was driven on the area twice, which is a common practice adopted by producers to enable the harvest of sods with characteristics for sale (whole, unbroken). Six $62.5 \times 40 \mathrm{~cm}$ (dimensions used for the sale of open sod pilled on pallets) sods were harvested per replication and piled up next to the plot from where they were cut. Sods were visually assessed to examine those that broke during the handling from harvest to piling. 


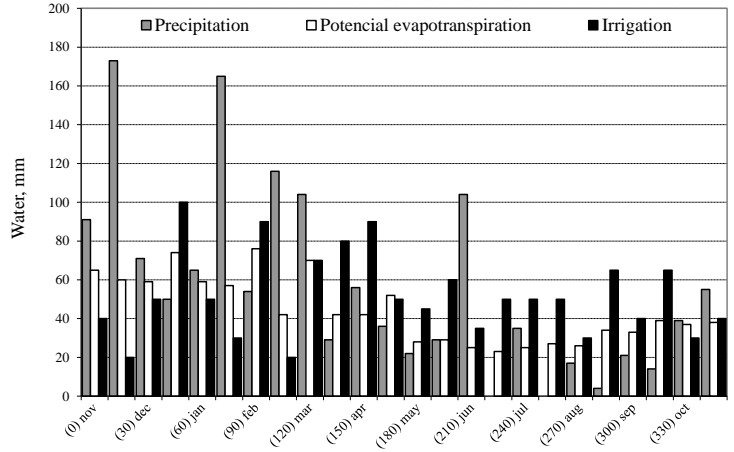

(Days after the harvest of the previous sod - HPS) Month

Figure 1. Precipitation, potential evapotranspiration, and irrigation in the municipality of Itapetininga as a function of days after the previous sod harvest at the beginning of the experiment. Source: CIIAGRO (2016).

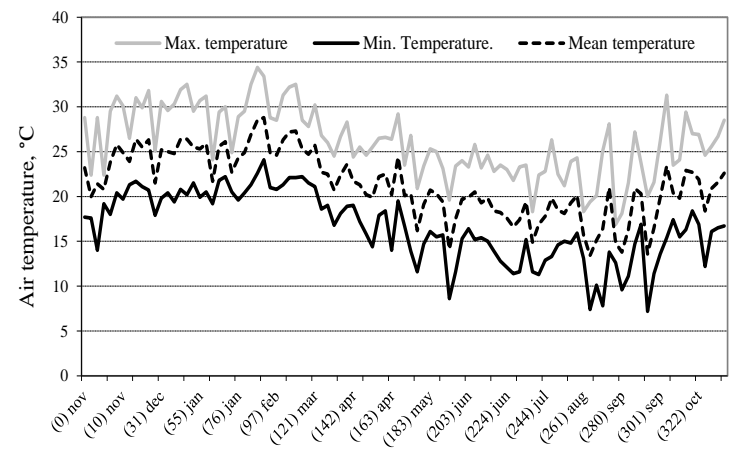

(Days after the harvest of the previous sod - HPS) Month

Figure 2. Maximum, minimum, and mean temperatures in the municipality of Itapetininga according to days after the previous sod harvest at the beginning of the experiment. Source: CIIAGRO (2016).

The percent ground cover of the turfgrass was evaluated by digital image analysis at 90 (Feb), 124 (Mar), 192 (May), and 296 (Sep) HPS. Digital images were obtained using a Fuji FinePix 4700 digital camera with $2.4 \mathrm{MP}$ zoom (Fuji Photo Film Co. LTD.) fixed at the extremity of the structure in an inverted "L" shape so that images were obtained parallel to the turf surface, at the same height (1.6 $\mathrm{m})$, avoiding the shadow of the photographer or any part of the camera. This procedure provided a digital image corresponding to the area, approximately $2 \mathrm{~m}^{2}$. Each picture was analyzed on Corel Photo Paint software v. 10.410, which determines the number of pixels of a certain color, according to adapted methodology of Richardson, Karcher and Purcell (2001). In this way, the turfgrass percent ground cover was determined by the methods of selection of pixels with green and straw colors (PGC) or selection of pixels with the ground color $\left(\mathrm{PGC}_{2}\right.$ ), while the percent green ground cover was obtained by selecting the green pixels (PGGC).

To determine the biomass, three samples of turfgrass sod were collected per plot, each measuring 36.3 $\mathrm{cm}^{2}$, using a stainless steel tube $(50 \mathrm{~cm}$ length $\times 8 \mathrm{~cm}$ diameter). Samples were washed to remove any adhering soil. Subsequently, the material was separated with tweezers into roots, stolons, and leaves + stems. Each part was dried in a forced-air oven for $72 \mathrm{~h}$ at $65^{\circ} \mathrm{C}$ and then weighed to determine the dry biomass. The obtained values were converted to $\mathrm{tha}^{-1}$.

After the dry biomass was determined, each plant material was ground and sent to the laboratory for determining the nutrient concentration, according to the method of Malavolta, Vitti and Oliveira (1997). Nutrient accumulation was calculated by multiplying the dry biomass by the nutrient concentration of each part (leaves + stem, rhizomes, stolons, and roots) of the turfgrass.

The Shapiro-Wilk normality test was applied. Results were subjected to analysis of variance, according to the $\mathrm{F}$ test at the $5 \%$ probability level, and regression equations were adjusted using SISVAR software version 5.6 (FERREIRA, 2011).

\section{RESULTS AND DISCUSSION}

Percent ground cover

At $90 \mathrm{HPS}$, the percent ground cover of the turfgrass (PGC, $\mathrm{PGC}_{2}$, and PGGC) was influenced by $\mathrm{N}$ doses $(p<0.05)$. Only one application of nitrogen had been performed to that date, and so there was no effect of split fertilization.

The quadratic model explained the variation in percent ground cover, and the estimated $\mathrm{N}$ doses of 157 , 167 , and $156 \mathrm{~kg} \mathrm{ha}^{-1}$ provided PGC, PGC , and PGGC of $89.5,88.4$, and $89.0 \%$, respectively (Figure 3 ). The similar cover percentages indicate that, at the highest $\mathrm{N}$ doses applied, practically all grass covering the soil was green.

There was no leaf injury problem with the use of the highest dose $\left(200 \mathrm{~kg} \mathrm{ha}^{-1}\right)$, because it would result in a lower PGGC compared with PGC or $\mathrm{PGC}_{2}$. In the USA, the recommended $\mathrm{N}$ dose for turf formed with $Z$. japonica should not exceed $50 \mathrm{~kg} \mathrm{ha}^{-1}$ per application (CARROW; WADDINGTON; RIEKE, 2001).

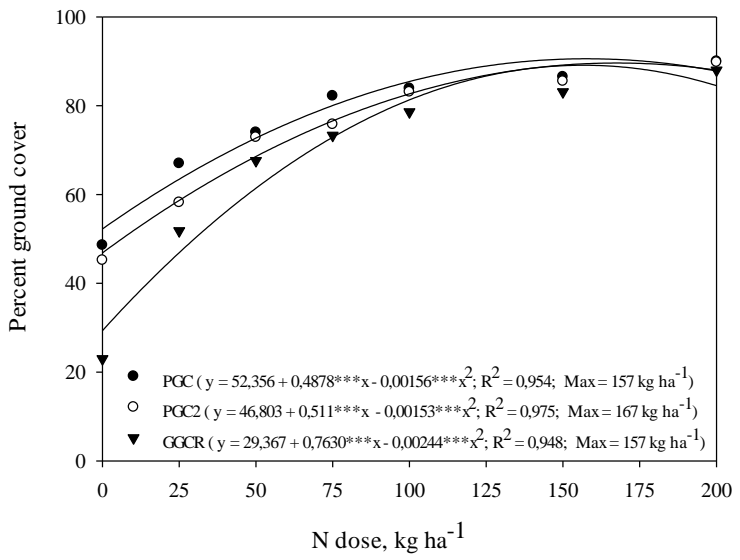

Figure 3. Percent ground cover (PGC and $\mathbf{P G C}_{2}$ ) and percent green ground cover (PGGC) of Emerald zoysiagrass (Zoysia japonica) according to $\mathrm{N}$ doses, at $90 \mathrm{HPS}$. *** - significant by $t$ test at $\mathrm{p}<0.001$. 
By the moment the nitrogen fertilizer was applied, the turfgrass covered around $41.9 \%$ of the soil, and this may be the reason why there was no leaf injury problem, at the highest dose. The use of lower doses per application may be linked to reduced chances of losses through leaching and may not provide fast shoot growth, requiring greater man labor for mowing. At the lower $\mathrm{N}$ doses $\left(0\right.$ and $\left.25 \mathrm{~kg} \mathrm{ha}^{-1}\right)$, the difference between $\mathrm{PGC}$ or $\mathrm{PGC}_{2}$ and $\mathrm{PGGC}$ is related to the $\mathrm{N}$ deficiency in these plots, which makes the leaves yellowish and gives their ends a straw color, which are not considered in PGGC.

Regarding the turfgrass that did not receive nitrogen topdressing, there was a $41.4 \%$ increase with the application of the highest $\mathrm{N}$ dose, which emphasizes the importance of applying this nutrient during this phase of rapid growth, with high temperatures (Figure 2) and good rainfall rates (Figure 1). Godoy et al. (2007) did not obtain an increase in PGC in Emerald zoysiagrass, from 71 to 116 HPS, due to the climatic conditions (low temperature and shorter photoperiod). According to Wei, Zhou and Li (2008), Zoysia must not be fertilized until the average night temperature reaches $10^{\circ} \mathrm{C}$ or more.

With this result, the decision for the $\mathrm{N}$ dose to be utilized according to the speed of formation of the desired sod can be adopted 60 days after the harvest according to the market's demand for turfgrass sods. If the demand is high, up to $160 \mathrm{~kg} \mathrm{ha}^{-1} \mathrm{~N}$ can be applied, aiming to reach $85 \%$ to $90 \%$ ground cover, but at a low demand, 25 to 50 $\mathrm{kg} \mathrm{ha}^{-1} \mathrm{can}$ be applied to reach a ground cover of 67 to $74 \%$, from $40 \%$ ground cover.

At 124 HPS, there was an effect of $\mathrm{N}$ doses $(\mathrm{p}<0.05)$ on all percent ground covers (PGC, PGC 2 , and PGGC) and of number of applications for PGC $(\mathrm{p}<0.05)$. On that date, the turfgrass that would receive the $\mathrm{N}$ dose split into six applications had received two, while the turfgrass that was to receive the dose into three applications had received only one. Additionally, on that day there was a significant interaction between number of applications and $\mathrm{N}$ doses, due mainly to the turfgrass that received $50 \mathrm{~kg}$ $\mathrm{ha}^{-1}$, in which application divided into two occasions allowed for a ground cover of $86.8 \%$ (PGC), while the same dose applied in one single occasion allowed the turfgrass to cover $79.1 \%$ of the ground (Figure 4 ). In the grasses from the other treatments (which received more than $50 \mathrm{~kg} \mathrm{ha}^{-1}$ $\mathrm{N}$ ), the difference in percent ground cover was too small for splitting the dose in one or two applications. The quadratic adjustment allowed for the calculation of the $\mathrm{N}$ doses of 184 and $189 \mathrm{~kg} \mathrm{ha}{ }^{-1}$ for PGC, at $124 \mathrm{HPS}$, for 3 and 6 applications, respectively (Figure 4). In the USA, recommended $\mathrm{N}$ doses for $Z$. japonica production typically do not exceed $60 \mathrm{~kg} \mathrm{ha}^{-1}$ per application (CHRISTIANS, 2011).

The quadratic adjustment of $\mathrm{PGC}_{2}$ and PGGC as a function of $\mathrm{N}$ doses allowed us to calculate the $\mathrm{N}$ doses of 167 and $170 \mathrm{ha}^{-1}$, which provided the highest cover percentages (Figure 5) at $124 \mathrm{HPS}$, which are slightly below the values calculated for PGC and close to those adjusted at 90 HPS.

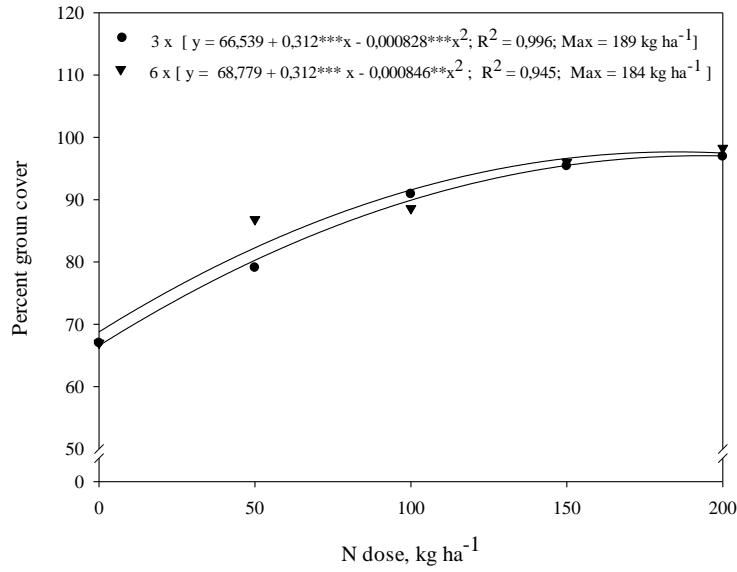

Figure 4. Percent ground cover (PGC) of Emerald zoysiagrass (Zoysia japonica) according to $\mathrm{N}$ doses, at 124 HPS; $3 \mathrm{x}-\mathrm{N}$ dose split in three times; $6 \mathrm{x}-\mathrm{N}$ dose split in six times; **, *** - significant by $t$ test at $\mathrm{p}<0,01$ and $\mathrm{p}<0,001$, respectively.

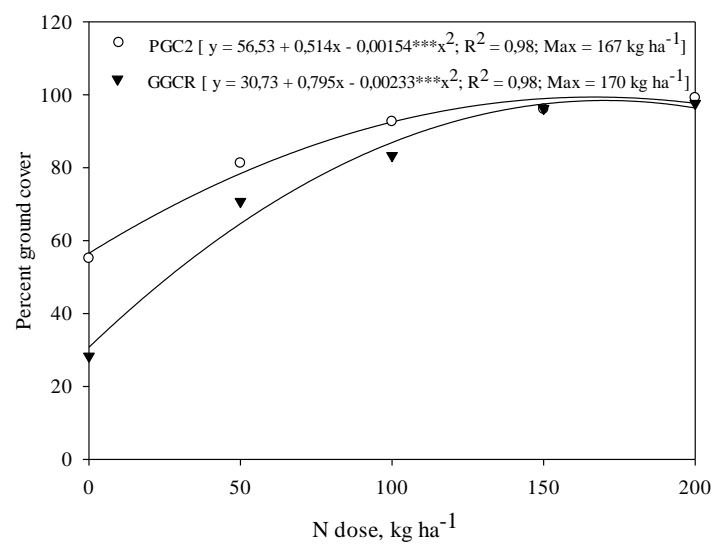

Figure 5. Percent ground cover $\left(\mathrm{PGC}_{2}\right)$ and percent green ground cover (GGCR) of Emerald zoysiagrass (Zoysia japonica) according to N doses, at 124 HPS. *** - significant by $t$ test at $\mathrm{p}<0.001$.

Although the turfgrass that received over $150 \mathrm{~kg}$ ha $^{-1}$ covered 97 to $99 \%$ of the ground, with over $95.5 \%$ green turfgrass, at 124 HPS it was not possible to harvest the sods, because $100 \%$ coverage is required. Small flaws in ground cover may lead to breakage of the sod structure during harvest, or during handling for carrying, resulting in a decline in yield (number of sods per hectare).

At 192 HPS, all cover percentages were influenced by $\mathrm{N}$ doses $(\mathrm{p}<0.05)$, with a significant effect of split applications $(\mathrm{p}<0.05)$ only on $\mathrm{PGC}_{2}$, in which application split into four occasions provided a higher $\mathrm{PGC}_{2}$ than when the turfgrass received $\mathrm{N}$ in two applications $(97.2 \%)$. The accumulated $\mathrm{N}$ doses split into two or four applications, at up to $192 \mathrm{HPS}$, were $100,200,300$, and $400 \mathrm{~kg} \mathrm{ha}^{-1}$. There was no significant interaction between doses and splitting.

The quadratic adjustment of $\mathrm{PGC}, \mathrm{PGC}_{2}$, and PGGC as a function of $\mathrm{N}$ doses indicated $\mathrm{N}$ doses of 309, 290 , and $301 \mathrm{~kg} \mathrm{ha}^{-1}$, which made it possible to achieve the highest cover percentages (Figure 6). In theory, at 192 HPS, according to $\mathrm{PGC}_{2}$, the grasses fertilized with the highest 
doses $\left(>300 \mathrm{~kg} \mathrm{ha}^{-1}\right.$ ) could be cut into a sod, with a $\mathrm{PGC}_{2}$ of 99.6 to $99.9 \%$ and with 94.4 to $96.0 \%$ green cover, in the turfgrass for which the dose was split into four applications. Similarly, Backes et al. (2009) evaluated the use of sewage sludge for production of Emerald zoysiagrass sod and found that at 165 days after application of $31 \mathrm{Mg} \mathrm{ha}^{-1}$ of sewage sludge (corresponding to $300 \mathrm{~kg} \mathrm{ha}{ }^{-1}$ available nitrogen) it resulted in $99.9 \%$ of the ground covered, with sods ready for harvest.

Therefore, the $\mathrm{N}$ dose of $400 \mathrm{~kg} \mathrm{ha}^{-1}$, split into four applications, at up to $196 \mathrm{HPS}$, allowed the harvest of the Zoysia japonica cv. Esmeralda grass sod in six months after the harvest of the previous sod. Pimenta (2003) mentioned the average time of 12 months for the harvest of Emerald zoysiagrass in Brazil, whereas Koske (1994) reported a period of 11 to 18 months for the formation of Zoysia grass in Louisiana State, South Central USA. According to Turner (2003), the right management of $\mathrm{N}$ in turfgrass production can reduce the harvest time and increase the turfgrass density and its ability to withstand invader plants and recover from stresses. However, as stated by Koske (1994), the use of higher doses and the too fast formation of the sod may compromise liftability (ability to be handled) by reducing the growth of rhizomes, the main factor responsible for the sod resistance (CHRISTIANS, 2011).

At $296 \mathrm{HPS}$, the effect of $\mathrm{N}$ doses on PGC, $\mathrm{PGC}_{2}$, and PGGC was significant $(\mathrm{p}<0.05)$; however, no effect of splitting was observed on percent ground cover $(\mathrm{p}>0.05)$. Although there was a good quadratic adjustment of the percentages in relation to $\mathrm{N}$ doses, the use of adjusted equations may lead to mistaken conclusions, regarding the higher doses utilized, because their increase in comparison with those observed at 192 HPS was minimal (less than $2 \%$ ) for an $\mathrm{N}$ addition of 150 to $200 \mathrm{~kg} \mathrm{ha}^{-1}$ (Figure 7). The low response can be explained by the fact that the turfgrass that had received more than $300 \mathrm{~kg} \mathrm{ha}^{-1}$ had already covered around $98 \%$ of the ground, and the maximum possible increase could only be $2 \%$. Therefore, the other $\mathrm{N}$ applications in these plots, respectively, of the $\mathrm{N}$ doses of 450 and $600 \mathrm{~kg} \mathrm{ha}^{-1}$, might have not been necessary, or a lower dose could be adopted.

From 97.3 to $98.8 \%$ ground cover at $192 \mathrm{HPS}$, the turfgrass fertilized with $200 \mathrm{~kg} \mathrm{ha}^{-1} \mathrm{~N}$ had covered $99.9 \%$ of the ground at $296 \mathrm{HPS}$ with the dose of $100 \mathrm{~kg} \mathrm{ha}^{-1}$, which was split into two applications or applied at once. Therefore, for the turfgrass that had already covered 99.5\% of the ground (which received more than $300 \mathrm{~kg} \mathrm{ha}^{-1}$ up to 192 HPS), the necessary dose at 192 HPS did not need to be greater than $100 \mathrm{~kg} \mathrm{ha}^{-1}$. Splitting the dose into two 50 $\mathrm{kg} \mathrm{ha}^{-1}$ applications could be advantageous to reduce the risks of leaf burning, since Zoysia japonica grass production becomes apparent at the percent ground cover $\left(\mathrm{PGC}_{2}\right)$ of $66.1 \%$ at 296 HPS, and only $9.1 \%$ of green cover in the turfgrass not fertilized with $\mathrm{N}$.

At 311 HPS, sods were harvested and only the turf that had not received topdressing was not able to form sod. The turf that received $150 \mathrm{~kg} \mathrm{ha}^{-1} \mathrm{~N}$ split into three or six applications, despite forming the sod, produced some that wound up breaking during harvest and became unusable for sale. The turf from the other treatments formed sods without losses due to breakage.

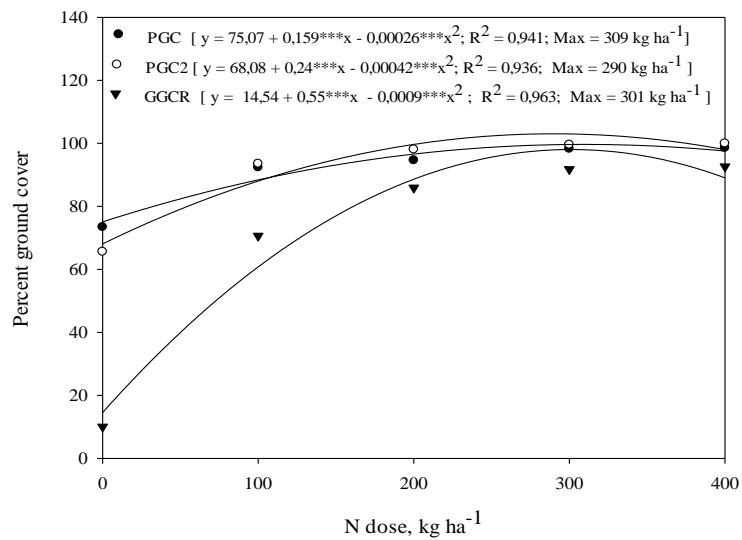

Figure 6. Percent ground cover (PGC and $\mathrm{PGC}_{2}$ ) and percent green ground cover (GGCR) of Emerald zoysiagrass (Zoysia japonica) according to $\mathrm{N}$ doses, at $192 \mathrm{HPS}$. *** - significant by $t$ test at $\mathrm{p}<0.001$.

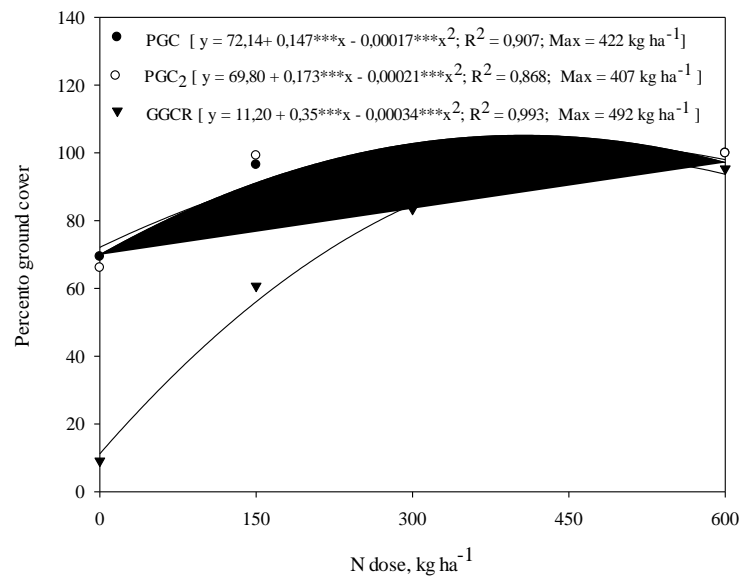

Figure 7. Percent ground cover (GCR) and percent green ground cover (GGCR) of Emerald zoysiagrass (Zoysia japonica) according to $\mathrm{N}$ doses, at 296 HPS. *** - significant by $t$ test at $\mathrm{p}<0.001$.

As previously discussed, nitrogen fertilization is determined by the market demand. Under regular sod demand conditions, a $\mathrm{N}$ dose of $75 \mathrm{~kg} \mathrm{ha}^{-1}$ can be applied, enabling the production of Zoysia japonica grass. When demand is low, $\mathrm{N}$ topdressing can be performed with three applications of 50 to $100100 \mathrm{~kg} \mathrm{ha}{ }^{-1}$, but the sod production time may be longer than 10 months.

Comparing the two methods for determining the percent ground cover, using the coefficient of variation (CV) - which, according to Zimmermann (2014), provides an estimate of the method precision -, we can conclude that at the beginning of the cycle, at 90 and 124 HPS, when the grass has not entirely covered the ground, PGC seems to be a little more precise $(\mathrm{CV}=3.4 \%)$ than $\mathrm{PGC}_{2}(\mathrm{CV}=4.4 \%)$ and PGGC $(\mathrm{CV}=9.4 \%)$. As for the other dates to evaluate the percent ground cover, $\mathrm{PGC}_{2}$ is a little more precise $(\mathrm{CV}$ $=0.4 \%$ ). Addressing the other percent ground cover 
evaluation methods, Richardson, Karcher and Purcell (2001) found that digital image analysis is 153 more times more precise than the method of evaluation by visual rates and 20 times more precise than the intersection method.

Dry biomass and macronutrient accumulation in leaves + stems, rhizomes + stolons, and roots

For the dry biomass of the turf parts, only an influence of $\mathrm{N}$ doses was detected $(\mathrm{p}<0.05)$, and no effect of $\mathrm{N}$ dose splitting was observed. The quadratic model explained the variation in total, rhizome + stolon, and leaf + stem biomass according to $\mathrm{N}$ doses (Figure 8).

Because root and rhizome production in the turfgrass sod production system is more important, as these components provide greater structure and resistance for the sod to be handled after harvest (CHRISTIANS, 2011), we can assume that the $\mathrm{N}$ dose of $400 \mathrm{~kg} \mathrm{ha}^{-1}$ is adequate, since it provided maximum root an rhizome production (Figure 8). Backes et al. (2013) obtained maximum sod resistance with the estimated composted sewage sludge dose of 46.9 $\mathrm{Mg} \mathrm{ha}^{-1}$ (corresponding to approximately $469 \mathrm{~kg} \mathrm{ha}^{-1} \mathrm{~N}$ ).

Doses greater than $400 \mathrm{~kg} \mathrm{ha}^{-1}$ can result in decreased production of rhizomes, stolons, and roots (Figure 8 ) and an increase in leaf + stem production (up to the dose of $450 \mathrm{~kg} \mathrm{ha}^{-1}$ ), which, according to Nobile, Nunes and Neves (2014), is not favorable from the economic perspective, since there will be excess leaf growth, which increase the need mowing and consequently nutrient extraction.

The amount of macronutrients accumulated in leaves + stems, rhizomes + stolons, and roots of Emerald zoysiagrass varied according to $\mathrm{N}$ doses $(\mathrm{p}<0.05)$. Splitting the doses into three applications provided the highest amount of $\mathrm{Ca}$ in leaves + stems; $\mathrm{P}, \mathrm{K}$, and $\mathrm{Ca}$ in the rhizomes + stolons; and $\mathrm{P}$ and $\mathrm{Ca}$ in the roots than when the dose was split into six applications (Table 1).

The amount of $\mathrm{N}$ accumulated in the rhizomes + stolons and leaves + stems increased linearly with the $\mathrm{N}$ doses, whereas the quantity of other accumulated macronutrients was adjusted according to the quadratic model (Figure 9). Because this is the nutrient required in the largest quantity by the crop, the higher amount applied provided greater leaf growth, thereby increasing dry biomass production and nutrient extraction.

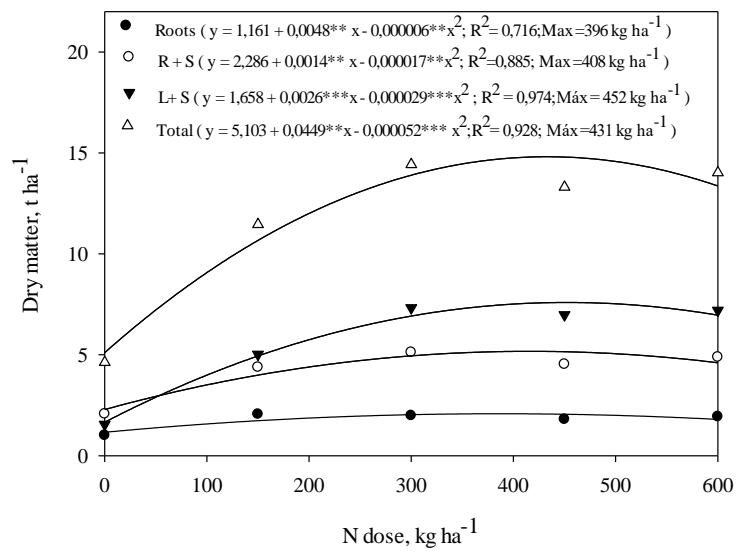

Figure 8. Biomass of roots, rhizomes + stolons $(R+S)$, leaves + stems $(\mathrm{L}+\mathrm{S})$, and total biomass accumulated by Emerald zoysiagrass (Zoysia japonica) according to $\mathrm{N}$ doses, at 296 HPS. *** - significant by $t$ test at $\mathrm{p}<0.001$.

Table 1. Amount of macronutrients accumulated in Emerald zoysiagrass ( $Z$. japonica) according to N doses, at $296 \mathrm{HPS}$.

\begin{tabular}{|c|c|c|c|c|c|c|}
\hline \multirow{3}{*}{ Treatment } & \multicolumn{6}{|c|}{ Accumulated macronutrient } \\
\hline & $\mathrm{N}$ & $\mathrm{P}$ & K & $\mathrm{Ca}$ & $\mathrm{Mg}$ & S \\
\hline & \multicolumn{6}{|c|}{----------------------------------- kg ha ${ }^{-1}$------------------------------- } \\
\hline & \multicolumn{6}{|c|}{ Rhizomes and stolons } \\
\hline $3 \mathrm{x}$ & $51.5 \mathrm{aA}$ & $3.8 \mathrm{aA}$ & $13.5 \mathrm{aA}$ & $8 \mathrm{aA}$ & $3.3 \mathrm{aA}$ & $6.2 \mathrm{aA}$ \\
\hline $6 \mathrm{x}$ & $46.5 \mathrm{aA}$ & $2.8 \mathrm{bA}$ & $10.9 \mathrm{bA}$ & $7 \mathrm{bA}$ & $2.8 \mathrm{aA}$ & $6.0 \mathrm{aA}$ \\
\hline \multirow[t]{2}{*}{ Control } & $8.9 \mathrm{~B}$ & $1.8 \mathrm{~B}$ & $7.2 \mathrm{~B}$ & $3.5 \mathrm{~B}$ & $1.2 \mathrm{~B}$ & $2.1 \mathrm{~B}$ \\
\hline & \multicolumn{6}{|c|}{ Roots } \\
\hline $3 x$ & $13.8 \mathrm{aA}$ & $1.4 \mathrm{aA}$ & $3.5 \mathrm{aA}$ & $5 \mathrm{aA}$ & $1.2 \mathrm{aA}$ & $2.3 \mathrm{aA}$ \\
\hline $6 x$ & $11.1 \mathrm{aA}$ & $1.0 \mathrm{bB}$ & $3.0 \mathrm{aA}$ & $4 \mathrm{bAB}$ & $1.0 \mathrm{aA}$ & $1.9 \mathrm{aA}$ \\
\hline \multirow[t]{2}{*}{ Control } & $4.6 \mathrm{~B}$ & $0.6 \mathrm{C}$ & $1.7 \mathrm{~B}$ & $3.4 \mathrm{~B}$ & $0.5 \mathrm{~B}$ & $0.9 \mathrm{~B}$ \\
\hline & \multicolumn{6}{|c|}{ Leaves and stems } \\
\hline $3 x$ & $86.6 \mathrm{aA}$ & $8.7 \mathrm{aA}$ & $39.2 \mathrm{aA}$ & $32 \mathrm{aA}$ & 8.9 aA & $17.5 \mathrm{aA}$ \\
\hline $6 x$ & $80.7 \mathrm{aA}$ & $8.4 \mathrm{aA}$ & $35.1 \mathrm{aA}$ & $26 \mathrm{abA}$ & $8.1 \mathrm{aA}$ & $15.1 \mathrm{aA}$ \\
\hline \multirow[t]{2}{*}{ Control } & $11.3 \mathrm{~B}$ & $2.2 \mathrm{~B}$ & $10.4 \mathrm{~B}$ & $7.8 \mathrm{~B}$ & $1.4 \mathrm{~B}$ & $2.7 \mathrm{~B}$ \\
\hline & \multicolumn{6}{|c|}{ Total } \\
\hline $3 x$ & $154.9 \mathrm{aA}$ & $13.9 \mathrm{aA}$ & $56.1 \mathrm{aA}$ & $46 \mathrm{aA}$ & $13.4 \mathrm{aA}$ & $25.9 \mathrm{aA}$ \\
\hline $6 x$ & $138.3 \mathrm{aA}$ & $12.2 \mathrm{aA}$ & $48.9 \mathrm{aA}$ & 38 aA & $11.9 \mathrm{aA}$ & $23.0 \mathrm{aA}$ \\
\hline Control & $24.7 \mathrm{~B}$ & $4.5 \mathrm{~B}$ & $19.2 \mathrm{~B}$ & $14.7 \mathrm{~B}$ & $3.2 \mathrm{~B}$ & $5.7 \mathrm{~B}$ \\
\hline
\end{tabular}

Means followed by common lowercase letters in the column do not differ between the split applications, by Tukey's test at $5 \%$. Means followed by common uppercase letters in the column do not differ between the split applications and control, by Tukey's test at $5 \%$ significance. 

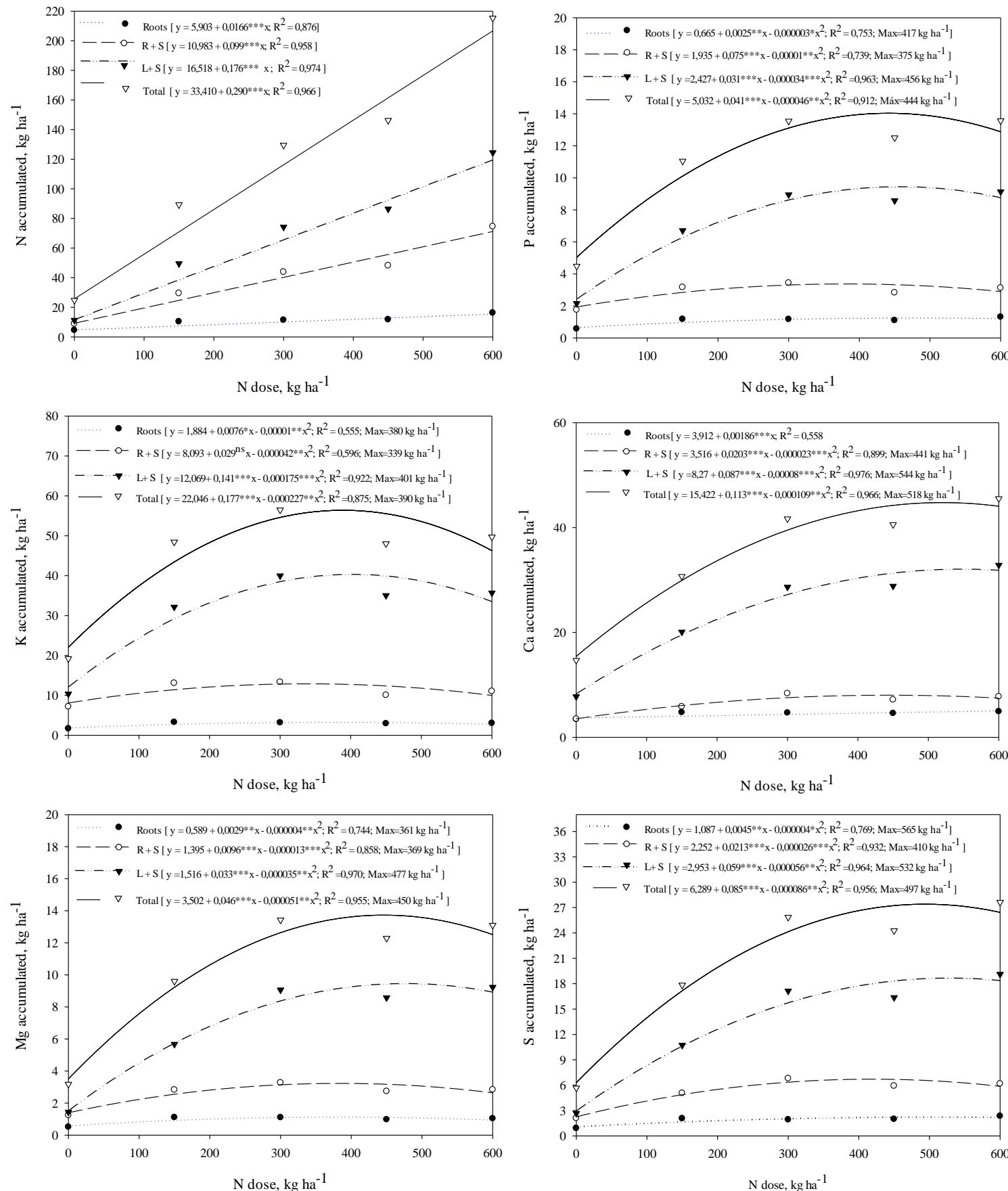

Figure 9. Accumulation of N, P, K, Ca, Mg, and S in roots, rhizomes + stolons $(\mathrm{R}+\mathrm{S})$, and leaves + stems $(\mathrm{L}+\mathrm{S})$ of Emerald zoysiagrass (Zoysia japonica) according to $\mathrm{N}$ doses. *, **, *** - significant by $t$ test at $\mathrm{p}<0,05, \mathrm{p}<0,01$ and $\mathrm{p}<0,001$, respectively.

The total $\mathrm{N}$ accumulated in the plant parts was $215.3 \mathrm{~kg} \mathrm{ha}^{-1}$ with the maximum applied dose $\left(600 \mathrm{~kg} \mathrm{ha}^{-1}\right.$ $\mathrm{N})$. Lima et al. (2015) also found a linear increase in the amount of $\mathrm{N}$ accumulated in the parts of bermudagrass as a function of $\mathrm{N}$ doses, with a $\mathrm{N}$ accumulation of $184 \mathrm{~kg} \mathrm{ha}^{-1}$ at the dose of $600 \mathrm{~kg} \mathrm{ha}^{-1}$ of this nutrient. Of the studied doses $\left(150,300,450\right.$, and $\left.600 \mathrm{~kg} \mathrm{ha}^{-1} \mathrm{~N}\right)$, plants recovered $59,43,32$, and $36 \%$, respectively. It should be stressed that, in our experiment, the clippings (from mowing) were not quantified, although they also represent nutrient export, since they are taken from the area. Backes et al. (2010) found that clippings exported $92 \mathrm{~kg} \mathrm{~N} \mathrm{ha}{ }^{-1}$ when the sewage sludge dose of $40 \mathrm{Mg} \mathrm{ha}^{-1}$ was added. For bermudagrass, Lima et al. (2015) obtained $204 \mathrm{~kg} \mathrm{ha}^{-1} \mathrm{~N}$ after applying the $\mathrm{N}$ dose of $600 \mathrm{~kg} \mathrm{ha-1}$. This greater extraction by bermudagrass is explained by its greater growth and consequent larger amount of accumulated biomass (5.567 $\left.\mathrm{kg} \mathrm{ha}{ }^{-1}\right)$.

According to the adjusted equation (444 $\mathrm{kg} \mathrm{ha}^{-1}$ $\mathrm{N}$ ), the maximum amount of $\mathrm{P}$ accumulated in the grass was 
$14 \mathrm{~kg} \mathrm{ha}{ }^{-1}$. Higher $\mathrm{N}$ doses provided lower nutrient accumulation, because they also reduced the dry biomass of rhizomes, stolons, and roots. For bermudagrass, $16 \mathrm{~kg} \mathrm{ha}^{-1}$ was extracted in the treatments that received $600 \mathrm{~kg} \mathrm{ha}^{-1} \mathrm{~N}$ and $80 \mathrm{~kg} \mathrm{ha}^{-1} \mathrm{P}_{2} \mathrm{O}_{5}$ (LIMA et al., 2015). According to Vietor et al. (2004), the P transported with the sod can improve the fixation rate, recovery, and quality of turfs when the harvested sod is transplanted.

The maximum amount of $\mathrm{K}$ when the sod was removed was $54 \mathrm{~kg} \mathrm{ha}^{-1}$, at the estimated $\mathrm{N}$ dose of $390 \mathrm{~kg}$ $\mathrm{ha}^{-1}$. Considering the amount of $\mathrm{K}$ applied, there was a $61 \%$ use rate. Potassium is the second larger used nutrient by grasses, and its importance in production, according to Godoy et al. (2007), lies mainly in the economy of irrigation water, since plants well-nourished with $\mathrm{K}$ lose less water by transpiration.

The maximum $\mathrm{Ca}, \mathrm{Mg}$, and $\mathrm{S}$ values accumulated and removed by Emerald zoysiagrass with the sod, according to the adjusted equations, were 45,14 , and $27 \mathrm{~kg}$ $\mathrm{ha}^{-1}$, at the $\mathrm{N}$ doses of 518,450 , and $497 \mathrm{~kg} \mathrm{ha}^{-1}$ respectively.

\section{CONCLUSIONS}

The $\mathrm{N}$ dose of $400 \mathrm{~kg} \mathrm{ha}{ }^{-1}$ split into four applications monthly, provided the highest number of Emerald zoysiagrass sods formed, six months after the previous sod had been harvested.

Nutrient extraction by Emerald zoysiagrass occurs in the following descending order, in $\mathrm{kg} \mathrm{ha}^{-1}: \mathrm{N}(207)>\mathrm{K}$ (57) $>\mathrm{Ca}(45)>\mathrm{S}(27)>\mathrm{P}(14)=\mathrm{Mg}(14)$.

The evaluation of percent ground cover by turfgrass by digital image analysis was accurate.

\section{REFERENCES}

BACKES, C. et al. Uso de lodo de esgoto na produção de tapetes de grama esmeralda. Ciência Rural, v. 39, p. 10451050, 2009.

BACKES, C. et al. Produção, acúmulo e exportação de nutrientes em grama esmeralda adubada com lodo de esgoto. Bragantia, v. 69, n. 2, p. 413-422, 2010.

BACKES, C. et al. Doses de lodo de esgoto compostado em produção de tapete de grama esmeralda imperial. Revista Brasileira de Ciência do Solo, v. 37, p. 1402-1414, 2013.

CARROW, R. N. E; WADDINGTON, D. V.; RIEKE, P. E. Turfgrass soil fertility and chemical problem: assessment and management. Chelsea, MI: Ann Arbor Press. 2001. 400 p.

CIIAGRO - Centro Integrado de Informações Agrometereológicas. Dados climáticos. Disponível em: <http://ciiagro.iac.sp.gov.br>. Acesso em: 21 de out. 2016.
CHRISTIANS, N. E. Fundamentals of turfgrass management. 4 ed. Hoboken, N.J.: John Wiley and Sons. 2011. 424 p.

FERREIRA, D. F. Sisvar: a computer statistical analysis system. Ciência e Agrotecnologia, v. 35, n. 6, p. 1039-1042, 2011.

GODOY, L. J. G.; VILLAS BOAS, R. L. Produção e consumo de gramas crescem no Brasil. In: Agrianual Anuário da Agricultura Brasileira. 10 ed., São Paulo: FNP Consultoria agro informática, p. 35-38, 2005.

GODOY, L. J. G. et al. Doses de nitrogênio e potássio na produção de grama esmeralda. Ciência e Agrotecnologia, v. 31, n. 5, p. 1326-1332, 2007.

GODOY, L. J. G.; VILLAS BÔAS, R. L.; BACKES, C. Produção de tapetes de grama Santo Agostinho submetida a doses de nitrogênio. Semina: Ciências Agrárias, v.33, n. 5, p. 1703-1716, 2012.

KOSKE, T. J. Sod production for Louisiana. 1994. Disponível em: $<$ http://www.lsuagcenter.com/en/lawn garden/commerc ial horticulture/turfgrass/sod farming/Sod+Production+ in+Louisiana.htm >. Acesso em 10 dez. 2014.

LIMA, C. P. et al. Bermuda grass sod production as related to nitrogen rates. Revista Brasileira de Ciência Solo, v. 34, n. 2, p. 371-378, 2010.

LIMA C. P. et al. Quantidade de nutrientes extraídos pela grama bermuda em função de doses de nitrogênio. Revista Bioscience Journal, v. 31, n. 5, p. 1432-1440, 2015.

MALAVOLTA E.; VITTI, G. C.; OLIVEIRA, S. A. Avaliação do estado nutricional das plantas: princípios e aplicações. 2.ed. Piracicaba: POTAFOS, 1997. 319 p.

NOBILE, F. O.; NUNES, H. D.; NEVES, J. C. Doses de lodo de esgoto sobre desenvolvimento da grama bermuda (Cynodon dactylon). Nucleus, v. 11, n. 2, p. 271-281, 2014.

PATTON, A. J.; REICHER Z. J. Zoysiagrass species and genotypes differ in their winter injury and freeze tolerance. Crop science, v. 47, n. 4, p. 1619-1627, 2007.

PIMENTA, C. H. Produção de gramas. In: SIMPÓSIO SOBRE GRAMADOS, 1., Botucatu. Anais... Botucatu: Departamento de Recursos Naturais, Faculdade de Ciências Agronômicas, Universidade Estadual Paulista. 2003. 1 CDROM.

RICHARDSON, M. D.; KARCHER, D. E.; PURCELL; D L. C. Quantifying turfgrass cover using digital image analysis. Crop Science, v. 41, p. 1884-1888, 2001. 
SANTOS H. G. et al. Sistema brasileiro de classificação de solos. Brasília. 3 ed. Brasília, DF: Embrapa. 2013. 353 p.

TURNER, T. R. Nutrient management guidelines for sod production in Maryland. University of Maryland. 2003. Disponível

em: $<$ http://www.mdaturfcounci.org/edu/pdfs/TT-02.pdf $>$. Acesso em: 22 set. 2015.

VIETOR D. M. et al. Runoff losses of phosphorus and nitrogen imported in sod or composted manure for turf establishment. Journal of Environmental Quality, v. 33, p. 358-366. 2004.

ZANON, M. E.; PIRES, E. Situação atual e perspectivas do mercado de grama no Brasil. In: Godoy, L.J.G et al. Tópicos atuais em gramados II. Botucatu: FEPAF. 2010. p.47-53.

ZIMMERMANN, F. J. P. Estatística aplicada à pesquisa agrícola. - 2. Ed. Brasília, DF: Embrapa, 2014 .582p.

WEI, S.; ZHOU, Y.; LI, D. Cold sensitivity and biochemical adjustments in zoysiagrass under low temperature stress. Acta Horticulturae, v. 783, p. 195-206, 2008. 